\title{
GOODBYE TO THE BODY AND THE SOUND OF SILENCE IN THE EXAMPLE OF THE MOVIE SOUND OF METAL
}

\author{
Mihriban ŞENSES*
}

\begin{abstract}
In this text, the movie "Sound of Metal" is discussed in terms of body philosophy, body anthropology, and health sociology. Sound of Metal is about the experiences of a person and couple after hearing loss. This film has been examined especially with reference to David Le Breton's important works titled Goodbye to the Body, Anthropology of Pain and Ivan Illich's Medical Nemesis: The Expropriation of Health. In the film, Ruben's focus on bodily loss and the process of not being able to cope with it are actually discussed through the mind-body distinction of the modern age, the desire of man to transform into a mind or a machine, and the social and cultural iatrogenesis that Illich mentions. It is also emphasized in the text that health, illness, physical "losses" are cultural, political or sociological phenomena rather than individual, physiological, medical issues and that they should be approached differently. In addition, it has been argued that human ontologically is an ear/hearing/speech/language/meaning entity, but modern scientific, medical and technological culture imprisons humans in a mechanical, visual and technical world. The result of such a culture is undoubtedly the loss of meaning that many thinkers bring to the agenda in their criticism of modernity. Therefore, the scientific, technological, medical culture we live in has to be re-evaluated based on these philosophical and sociological criticism points.
\end{abstract}

Keywords: Goodbye Body, Medicalization, İatrogenesis, Mind-Body Distinction.

\section{SOUND OF METAL FİLMİ ÖRNEĞİNDE BEDENE VEDA VE SESSİZLİ̆İN SESİ}

ÖZ

Bu metinde "Sound of Metal" ("Metalin Sesi") filmi beden felsefesi, beden antropolojisi, sağl1k sosyolojisi mülahazalarından hareketle ele alınmaktadır. Sound of Metal filmi bir insanın ve çiftin işitme kaybı sonrasında yaşadığı deneyimleri konu edinmektedir. Bu film özellikle David Le Breton'un Bedene Veda, Acının Antropolojisi adlı önemli çalışmalarından ve Ivan Illich'in Sağlığın Gaspı eserinden hareketle incelenmiştir. Filmde Ruben'in bedensel kayba odaklanması ve bununla baş edememe süreci aslında modern çağın zihin-beden ayrımı, insanın zihne ya da makineye dönüşme arzusu ve Illich'in sözünü ettiği sosyal ve kültürel iatrojenez üzerinden tartışılmıştır. Metinde aynı zamanda sağlığın, hastalığın, fiziksel "kayıp"ların bireysel, fizyolojik, tıbbi meseleler olmaktan çok kültürel, politik ya da sosyolojik fenomenler olduğu ve bunlara farklı şekilde yaklaşılması gerekliliği vurgulanmıştır. Ayrıca insanın ontolojik olarak kulak/işitme/söz/dil/anlam varllğı olduğu, fakat modern bilimsel, tıbbi, teknolojik kültürün insanı mekanik, görsel, teknik bir dünyaya hapsettiği ileri sürülmüştür. Böyle bir kültürün sonucu da hiç kuşkusuz birçok düşünürün modernite eleştirisinde gündeme getirdiği anlam kaybıdır. Dolayısıyla içinde bulunduğumuz bilimsel, teknolojik, tıbbi kültür felsefi ve sosyolojik bu eleştiri noktalarından hareketle yeniden değerlendirilmek zorundadır.

Anahtar Kelimeler: Bedene Veda, Tıbbileştirme, İatrojenez, Zihin-Beden Ayrımı.

Atıf: ŞENSES, M. (2021). "Sound of Metal Filmi Örneğinde Bedene Veda ve Sessizliğin Sesi”, İMGELEM, 5 (9): 367-379.

Citation: SSENSES, M. (2021). "Goodbye to the Body and the Sound of Silence in the Example of the Movie Sound of Metal", IMGELEM, 5 (9): 367-379.

Başvuru / Received: 23 Ağustos / August 2021.

Kabul / Accepted: 18 Kasım / November 2021.

Derleme Makale / Review Article.

\section{INTRODUCTION}

In the text in your hand, the movie "Sound of Metal" has been tried to be interpreted from different philosophical, anthropological and sociological perspectives. This film is about

\footnotetext{
${ }^{*}$ Dr. Öğr. Üyesi, Bursa Teknik Üniversitesi, İnsan ve Toplum Bilimleri Fakültesi Sosyoloji Bölümü, E-mail: mihrisenses@gmail.com, ORCID Number: 0000-0001-8021-9835
} 


\section{Goodbye to the Body and The Sound of Silence in the Example of the Movie "Sound of Metal"}

the transformations in the life of an individual with hearing loss and the couple due to this loss. In the following section, firstly, the summary of the film is included, then the content analysis of the film is made based on Goodbye to the Body and Anthropology of Pain which are the important works of David Le Breton and Medical Nemesis: The Expropriation of Health by Ivan Illich. In this text, the reason why the movie Sound of Metal was chosen in terms of content analysis is that the topics discussed in the mentioned texts are compatible with the movie.

David Le Breton explains "Goodbye to the Body" through the mind-body distinction of Plato (form-matter), Christianity, gnosticism and the tradition that started with Descartes in the modern age. According to this distinction, the essence is the mind, not the body. In these traditions, the body represents the deteriorating and decaying side of humankind. According to this, human is actually a mind being rather than a body being. In the modern age, this understanding, which is combined/blended with science, technology and especially medical culture, has brought along the process of transcending the body, transforming human into the mind, machine/artificial intelligence. Undoubtedly, Newtonian mechanical universe and modern mechanical human understanding also have a share in the emergence of this process. This understanding has transformed the human into a machine in the medical world, through industrialization, the development of technology and capitalism. But, of course, man is not a machine, and diseases or losses are not phenomena to be approached mechanically or biologically. Likewise, man is not just a mind being.

In this text, the movie Sound of Metal is discussed through the aforementioned goodbye to the body, transcending the body, transforming into a being of mind, and the criticism of mechanical approaches. The fact that Ruben thinks that he can live his old life in the same way thanks to a device after his hearing loss in the movie is exactly the result of the above-mentioned approaches or understandings. Unfortunately, Ruben could not solve the meaning problem in his life with a hearing aid that would enable him to hear, which could not provide enough natural sense of hearing, and he could not continue his routine from where he left off. After all, modern medicine (along with science, technology, industrialization and capitalism) is responsible for clinical, social and cultural iatrogenesis in many other cases, as in Ruben's case, as Illich emphasized. It is possible to evaluate Ruben's inability to cope with his hearing loss and his behavior as an "addict" to this loss in the movie Sound of Metal as a kind of social and cultural iatrogenesis. Here based on all these, in this text, the problem of coping with illness, loss, pain or giving meaning to them is also discussed with reference to the book Anthropology of Pain. 
Finally, in this study, it is emphasized that human beings are not only a mental being, that they cannot be seen as a machine, and that humans are actually a language and meaning being. Therefore, it has been argued that the current understandings of science, technology and medicine should be subjected to criticism -both philosophically and sociologically-, and revised and organized accordingly.

Year: 2020 Director: Darius Marder Screenplay: Darius Marder, Abraham Marder Cast: Riz Ahmed, Olivia Cooke, Paul Raci, Lauren Ridloff, Mathieu Amalric, Domenico Toledo, Chelsea Lee et al.

\section{Summary of the Movie:}

The name of the film, which was awarded the best editing (Mikkel E.G. Nielsen) and best sound awards at the 2021 Oscar Awards, is "Sound of Metal"; however, in fact, this sound is neither the sound of music nor the sound of metal music, but the sound of restlessness, confusion, addiction and the artificial sound of machine.

The film, which deals with hearing loss and its aftermath, begins by introducing us to the daily lives of Ruben and Louise couple. This couple, who used drugs and attempted suicide a few years ago, actually saved each other's lives. At the end of this process, they started to make metal music together and live in a caravan. Director Marder starts the film with a night where this couple makes music. As we understand from the stage, both drummer Ruben and vocalist Louise take great pleasure in making music. Because of this opening scene of the movie, the audience initially thinks that Sound of Metal, that is, the name of the movie, describes the sound of music or metal music. However, from the chaos of the night, it can be understood that the music performed is also a harbinger of unrest. In the next scene, we see sequences of Ruben and Lou's life in the caravan. Ruben prepares a healthy breakfast for his girlfriend Lou. However, he also gives an important detail here: "You'll hate it, it's disgusting, but it's healthy," he says of the fruit puree he prepares.

As everything is going on in its normal course, Ruben realizes that he hears very little, that is, hearing loss, and goes to the doctor. The doctor tells Ruben that his hearing loss is very advanced, that he will not be able to hear it again, that the music he makes will cause him to lose his hearing completely, so he has to quit music and he can continue his life with a hearing aid implant from now on. Unfortunately, this hearing aid is also extremely expensive. The radical transformation in Ruben and Louise's life begins right after that. Because, after Ruben's hearing loss, he will no longer be able to make music, hear the world, nature and sounds as 


\section{Goodbye to the Body and The Sound of Silence in the Example of the Movie "Sound of Metal"}

before, and will not be able to communicate with people as before. However, soon after learning about his hearing loss, Ruben wants to continue music and they perform with Lou. From this, we understand that human do not want to give up their lifestyle quickly; even if this lifestyle costs them their health. This will turn into an existential problem for Ruben to question his identity(s) in life.

As Ruben tries to find himself again, he meets a community of former addicts with hearing loss. The leader of this community is Joe, a former alcohol addict who lost his hearing in the Vietnam War. Joe tries to explain to Ruben that he must accept this process and learn to live with this "loss". Although Ruben does not want to accept this situation, he joins this community with Lou's persuasion. In fact, there are some rules that the community applies to avoid or get rid of all addictions in life. For example, instead of seeing hearing loss as a defect, deficiency or deterioration, people here try to live with it and try to shape or live their lives away from all kinds of addictions (they are forbidden to use phones, computers, etc.). Here, Ruben, with Joe's guidance tries to learn to be on his own, to listen to silence or stillness. Here he makes good friends and learns sign language.

While everything is going well, Ruben watches a video of his girlfriend and wants to go back to his previous life. He sells his caravan and musical instruments and, thinking that everything will be the same as before, gets the implant he so wanted. Because he has sold everything, Ruben has no job, no money to sustain his life, and no place to stay until the implant is active. He asks Joe if, with the help of the Church (which helps such communities), he can borrow some money from the community and let him stay in the community for a few weeks. Unfortunately, Joe's answer to Ruben is negative; Joe tells him with a very impressive expression that he looks and speaks just like an addict. In fact, Joe is consistent and right, given his and the community's purpose. Because people in this community do not see a disorder in their bodies that needs to be repaired and eliminated. Therefore, Ruben's presence in the community will harm the order, body and life perception or imagination of the people here. As a result, Joe says that Ruben can find himself in his next life, that he can reach the silence (actually different voice) and calmness inside him when he needs it, and he parted ways with Ruben.

Once the hearing aid device is activated, a much more challenging process begins for Ruben. Because the sounds provided by the implant are far from meeting Ruben's expectations. Ruben takes his disappointment with him and goes to his girlfriend Lou. Lou has moved in with 
his long-lost father, whom she blames for his mother's death, and although there is no one else in her life, she is no longer the person Ruben had dreamed of, or expected; because not only her physical appearance, the traces of his suicide attempt, but also her whole life has changed. All these changes are accompanied by the radical change that Ruben experienced after his hearing loss. Ruben's way of communicating with music, people and the world has changed, and he has actually lost touch with Lou. Both are aware that they can no longer return to their old lives, and Ruben quietly walks out of Lou's life because of this; In silence, he makes his way to the world where he will find or hope to find the voice again.

\section{Goodbye To The Body and The Sound Of Silence In the Example of "Sound of} Metal"

"I can't be that set of organs called the body."

René Descartes

Although the synopsis of the film can be limited as above, the subject to be discussed in this text is much more comprehensive. The subject(s) covered in this movie will be tried to be evaluated based on some considerations in body philosophy, body anthropology, body sociology, and health sociology in general. First of all, let's start with David Le Breton's book Goodbye to the Body, who mostly works on body anthropology.

Breton begins this book with Descartes' quotation, "'I cannot be that set of limbs called the human body'" (Breton 2019:9). In fact, it is possible to trace the way of thinking that is meant to be expressed in this sentence back to Plato. The idea that emerged in the philosophy of both Plato and later Descartes as the founder of modern philosophy (It is possible to evaluate modern philosophy as a return to Plato in the sense of emphasizing mathematics, geometry, rational, measurable and calculable) is "goodbye to the body". So what does it mean to say goodbye to the body?

Saying goodbye to the body in Plato's philosophy means that the world of ideas or forms takes priority over the material world/world of shadows, and the mind over the body. In Plato's thought, "the body is the tomb of the soul." (2019: 9) Unlike the soul, the body represents the world of imperfect, deteriorating and decaying matter. However, the soul belongs to the world of forms-ideas that are not subject to corruption. Therefore, the essence of Plato's thought is the soul and the mind. (A philosopher is also a person who can escape from the world of matter/shadows and reach the world of ideas/forms with his mind.) 


\section{Goodbye to the Body and The Sound of Silence in the Example of the Movie "Sound of Metal"}

In fact, Plato, with his negative view of the body, reduced man to a kind of "pure mind". (Heidegger 2011: 421-422) Because in the history of Western thought, the negative point of view that we have mentioned about the body has preserved its existence since the pre-Socratics. It is possible to see the reflections of this point of view in Christianity and gnosticism.

"Gnostics take the hatred of the body to its extreme, seeing it as an incurable shame. The soul falls into the body... and is wasted there. Skin is man's cursed share of predestined aging, death and disease. It is 'carrion', it is 'flesh"', (2019: 19).

Actually, the modern age have also followed the Platonic tradition we mentioned above and approached the body negatively. As it is known, the mind-body dualism crystallized with Descartes, who is accepted as the founder of modern philosophy or epistemology. Together with the ego cogito/thinking ego, man is reduced to the "thinking animal", to the "pure mind".

"Descartes breaks the link between intelligence and flesh and blood body. The body is for him the mechanical shell of a presence, in the final analysis it can be substituted, because the essence of man is primarily in the cogito. According to this premise of the 'hard disk' in Artificial Intelligence; Man consists of his intelligence, and the body is only a hindrance" (2019: 15).

As Breton stated, modern man aims to get rid of the body, which represents weakness, defect, deterioration and decay. In the modern era, too, "the body is the embodiment of evil; it is a draft that can be corrected" (2019: 12). According to today's dominant understanding of science and technology, man suffers from a corporeality that constantly reminds him of his inability. Modern man

"resents his body, which bears the mark of original sin, that is, of not being a pure object of scientific-technical creation. The body is an endemic disease of the mind or the subject... The task of rehabilitating or eliminating the body, a harmful invention of human history, falls to genetics, robotics or informatics" (2019: 12).

It is also possible to associate this approach, which is seen as a mechanical approach to the human or the body, with the Newtonian understanding of the universe. Together with the Newtonian understanding of the mechanical universe and the Cartesian way of thinking, the universe and human were perceived as machines. ${ }^{\text {ii }}$ According to this mechanical understanding of human and the universe, human and the universe work just like a clock or a machine. The laws and rules of this functioning process/algorithm can be known, determined and regulated absolutely. According to this understanding, man and the universe can be controlled like a machine. According to this understanding, the body is a machine that can be removed, repaired and recreated. 
Today, we constantly interfere with this machine to sleep, stay fit, become thin or more muscular, reduce anxiety, be more energetic. In this way, we want to transform the body, which we find inadequate, into a machine that functions more effectively, responds more to the system or is more accepted in the system. In fact, we want to attain salvation by changing the body, to bid farewell to the body and become pure mind, that is, actually a kind of God. Breton deals with this in a very impressive way in his book Goodbye to the Body, with examples such as piercing, tattooing, body art, body building, drugs, subcutaneous implants, in vitro fertilization (child manufacturing), genetic engineering, and the virtual world (2019: 19-23).

Today's people can gain a new identity with piercings, tattoos, body building, body art, aesthetic operations, implants, transform their body into a showroom where the image is displayed, hide the "flaws" and weakness of the body, and could possess symbolic capital through the body, as Pierre Bourdieu stated. All this also means transcending the body and believing that man can transform themselves into God.

In this understanding, human is not a mentally and physically integrated being. Human is no longer an entity trying to understand and listen to himself/herself, his/her feelings, and his/her body. Because, as Breton stated, it has the power to suppress, silence, eliminate anxiety, fatigue, pain, suffering, everything that is seen as a defect, deficiency, inadequacy in the body; moreover, this power is often as close to him as a pill. Biochemical tools, prostheses, products are always at the service of man to silence the body. However, unfortunately, people fail to see that daily life and routine are medicalized to a terrible extent, their effects are limited and they forget their side effects (2019: 61-62).

Today, science, technology, in particular biology, genetic engineering and health have become religions. Today we live or feel compelled to live by the rules, precepts and sometimes dogmas of these new religions and clergy (scientists, experts, technocrats, medics, pharmacologists etc.) As science, technology and medicine surround our whole life, we seek the remedy in the rules or products that these fields offer us to feel what we need to feel and to turn our ears to the body's "protest" (2019: 63).

So what can be said about "Sound of Metal" based on all these? First of all, it is possible to argue that there can be a kind of "Goodbye to the Body" reading in the movie, especially through the character of Ruben. Ruben began to experience an existential panic during the hearing loss process and saw what he was experiencing as a malfunction in the machine, a breakdown and something that needed to be repaired urgently. Because Ruben also suffers from 


\section{Goodbye to the Body and The Sound of Silence in the Example of the Movie "Sound of Metal"}

the mind-body dualism we mentioned above and/or the mechanical understanding of man and the universe. This is exactly why Ruben does not try to understand or listen to himself, his lifestyle, and silence for a moment. Since he believes that what he perceives as a defect, defect or deficiency can be easily solved through science, medicine and technology, he wants it to be repaired as soon as possible.

However, it is possible to argue that science, technology and medicine represent the last stage when it comes to problems or diseases in human life. For example, Ruben relied on the solutions found by technology and medicine, even though it was his lifestyle, the drugs he used, the loud music he made that caused his hearing loss.

In fact, while people are getting sick, getting depressed and sufferring because of today's stressful life conditions, social order (actually its chaos), ecological problems, what they eat, drink, etc.; Instead of looking at the big picture, experts, doctors, scientists, politicians and technocrats try to reduce health to an individual issue and to produce "artificial" iii solutions to the problems and diseases produced by the current order through medicine, science and technology. However, health and illness are not only individual but political issues or phenomena.

In the social order we live in today, or in the health system in particular, health is presented as if it is an individual issue, and the products that individuals should use to stay healthy, healthy foods they should consume, living conditions or styles are imposed on them, every day through the media what is "needed" is pumped, culture is medicalized and the individual is approached as if he is responsible for his own health and illness in the current order (Sezgin 2011). However, as in the Ruben example, the individual is not solely responsible for his lifestyle, the products he eats/drinks, the polluted air he breathes, the stressful life conditions, the negative consequences of industrialization, the wrong political decisions, the damages or side effects of the products or drugs he uses. Of course, people act and make choices with their "free will" to some extent. ${ }^{\text {iv }}$ However, for example, in the case of the USA, blacks, Latinos, Mexicans die more due to heart attacks, (deaths of Navajo Indians due to alcoholism - which they see as fate due to their painful experiences, traumas) strokes, traffic accidents, hypertension, have less health insurance, more mental hospitals, about forty percent of US citizens suffer from obesity, diets are not just about individuals' choices. In terms of health sociology, all these are issues that need to be addressed socially, culturally, economically and politically (Aytaç and Kurtdaş 2015). 
Going back to the film, we can argue that it is also possible to discuss the issue of iatrogenesis mentioned by Ivan Illich through the subject discussed here and Ruben. As it is known, Illich deals with iatrogenesis under three headings in his work called Medical Nemesis which is accepted as one of the important texts in the sociology of health. Clinical iatrogenesis refers to the disease or harm of the patient due to clinical, treatment, diagnosis. Social iatrogenesis is a type of iatrogenesis that describes the medicalization of life and the dependence of society on medicine. Cultural iatrogenesis means that individuals no longer have traditional ways of coping with pain, illness, and death, and people become completely helpless against them without medical expertise (Illich 2017). In the movie "Sound of Metal", this cultural iatrogenesis issue is actually discussed. In the film, Ruben is described as "addicted" when he enters a community trying to make sense of and resolve hearing loss through sign language and calmness, and when he is concerned about hearing loss there. Because Ruben does not know how to deal with this loss or how to try to make sense of this loss, and he is suffering. This is the social and cultural iatrogenesis itself. According to mechanical medicine and human understanding, when a malfunction occurs in the machine, with the effect of cultural iatrogenesis, people cannot resist and cope with this disruption. Since the human body is perceived as a machine here, the malfunction in this body must be corrected immediately and the machine must continue to function. In the film, it is possible to see the effects of this mechanical understanding in Ruben's hearing loss process. Ruben wants to make up for his loss immediately, and instead of listening to himself and the silence for a moment in this process, he seeks an urgent solution because he believes that the problem can be easily solved through science, medicine and technology.

It is also possible to associate this urgent search for solutions with the approach of modern medicine and culture to pain. Modern medicine and culture see pain as a mechanical thing that needs to be relieved and eliminated as soon as possible like other diseases and ailments. However, pain is not just a physical and biological issue, but it is a phenomenon with cultural and anthropological dimensions. Breton, in his Anthropology of Pain, deals with pain in its entirety with these different dimensions (Breton 2015).

For example, pain was also seen as a form of excitement in the Aristotelian tradition. In the Cartesian tradition, pain is associated with the body and sensations. Accordingly, pain is an overstimulation of the senses. But in fact, pain does not just have a sensory dimension. (So man is not a machine and pain cannot be seen as a mechanism.) Pain is essentially about human 


\section{Goodbye to the Body and The Sound of Silence in the Example of the Movie "Sound of Metal"}

experience of the world. Pain harms our relationship with the world and injures us spiritually (2015: 9-13). "Although modernity sees a painful archaism that medicine must eradicate as soon as possible,
one cannot always escape it. Pain also has social functions, and indeed it is an instrument that
can be pulled in many different directions. For example, the old-time Christian forgives his pain
and repays his debt because of Jesus' sacrifice. In this case, every suffering is a proof of love, a
worship... Pain is a sacred wound in the sense that it tears people away from themselves and
brings them face to face with their limits... When it strikes, it leaves no pleasure in living, on
the contrary, it reactivates this pleasure when it goes away. It reminds of enthusiasm for life. It
is a memento mori that leads to the essential" $(2015: 15,16)$.

In fact, people do not realize their bodies, the meaning of life, life or death, their daily routines, social relations, unless they are sick, feel bodily discomfort or pain. Pain makes one become aware of all these and their meanings. Canguilhem therefore defined health as: "The state of being unaware of one's body" (2015: 19). A person begins to become aware of his body with illness or pain and actually wants to make sense of the suffering. The disease takes on deeper meanings as it causes a complex relationship with the world. As Breton stated, understanding “one's pain is another way of understanding one's life" (2015: 99).

With the emergence of pain, man's relationship with the world, with other people, and with himself is transformed. Because pain is also a threat to a person's sense of identity. Because of pain, people give up or run away from themselves and social relations. However, whether pain is physical, social, spiritual, etc., it cannot be evaluated with its negative dimensions. ${ }^{\mathrm{v}}$ (2015: 21) Breton demonstrated this by examining the mechanisms by which different cultures perceive, make sense of, or cope with pain differently.

For example, as we mentioned above, pain was perceived as a form of excitement in Ancient Greece, and in the Greek tradition, a person who cannot cope with his pain is actually an unhappy person (Illich 2017: 108). "According to the Stoic moral understanding, pain is a wound that comes from a natural phenomenon in man. It gnaws at the body, but does not leave its mark" (Breton 2015: 69). Pain is often associated with sin in religions (especially Eastern religions). However, in Judaism, Christianity, and Islam, the reactions to pain or the way they make sense of it differ. For the Christian, suffering is associated with original sin. In Christianity, suffering is a form of purification, the possibility of salvation or atonement. In Jewish tradition, unlike Christianity, there is no room for asceticism or humiliation when it comes to suffering. People can resort to different ways to cope with their pain. Suffering in Islam is an expression of the transience of this world, and people should not give up their faith 
because of pain, on the contrary, they should take refuge in God and be patient (Breton 2015: 73-97).

In other words, past societies, religions and societies where modern medicine has not yet been developed or adopted have attributed very different meanings to pain and tried to cope with it differently. For example, before the development of modern medicine, hypnosis methods were used in surgeries so that the person who had the surgery did not suffer. Pascal tried to counter his relentless toothaches by engaging in mathematics and having fun. Suffering from gout, Kant focused on concepts or objects so that he could forget his pain or sleep. As in all these examples, pain is not simply a biological phenomenon; has different meanings and can be attained or dominated (2015: 66,71).

Unfortunately, since modern medicine focuses on pain and disease, not the patient and human being, pain has also turned into a purely mechanical, biological phenomenon. In the world we live in, despite all the optimistic discourses about modern medicine and the search for "miracle molecule", people continue to experience distress due to their diseases, ailments, aches or pains (2015: 17). As we can see in the movie Sound of Metal, the character of Ruben also suffers from this mechanical dimension of modern medicine, the medicalization ${ }^{\mathrm{vi}}$, the social and cultural iatrogenesis that Illich talks about

\section{CONCLUSION}

As a result, it is possible to argue that the perspectives on human, disease and society in the modern age have been shaped by the dichotomy of soul-body, mind-emotion, mechanical universe, mechanical human, mechanical society understandings that have become effective with the development of modern science, philosophy and technology. Ruben is also under the influence of the soul-body distinction we have mentioned. We have stated that this distinction actually results in man in the position of God (with the idea of God as man), as Breton indicated. Modern man tries to become a pure mind, a perfect machine, or turn into God. Because of mechanical approaches, modern man tries to overcome and to eliminate completely illness, pain or death instead of confronting them. However, the more natural and "normal" health and life are, the more natural and normal are sickness and death. And what makes man human, what makes it ontologically meaningful, is that he/she is a mortal being. Man gives meaning to life, himself or existence with death. Undoubtedly, he/she does this with language, or more accurately, in language (Dastur 2019). 


\section{Goodbye to the Body and The Sound of Silence in the Example of the Movie "Sound of Metal"}

As the hermeneutic tradition insistently emphasizes, human is basically the being of language and meaning. However, according to the modern way of thinking, human is a mind being. The most basic characteristic of a human being is to be able to think or to have reason. However, there is no doubt that the human mind does not think in a vacuum, and thought (actually, thinking is speaking) is impossible without language. Language is the biggest symbol system of human and social life. Man always thinks in symbols or symbol systems.

If the most basic feature of man is that he has language and meaning, then the most basic organ of man becomes the ear (According to the hermeneutic tradition, the most basic feature of man is not to have reason, but to be able to hear and speak). However, according to the modern age, the important thing is not the audible, word, but the visible, measurable, calculable and quantifiable. In this sense, the modern age is not the age of ear or hearing, but the age of eye or vision/ocularcentric age. Vision/eye culture ${ }^{\text {vii }}$ is images, mechanical, numerical, mathematical (mathematical is not numerical, numerical is mathematical ${ }^{\text {viii }}$ ), technical or material culture. In this culture, there is no place for the openness to Being, the voice of Being, the truth, or the voice of truth that Heidegger speaks of (Modern culture cares about reality, not truth; truth is about language, word, and meaning; reality is with facts and images.)

Again, according to this culture, people have lost their meaning when it comes to health and illness, as in other areas of life. In "Sound of Metal", Ruben's hearing loss is actually a loss of meaning, and Ruben unfortunately thinks that he can fix this loss of meaning with a "cold" machine. Unfortunately, as we understand from the movie, "Sound of Metal" is not the sound of music, but the sound of chaos and addiction; "Sound of Metal" is not sound of Being or meaning; but the sound of machine/metal. 


\section{REFERENCES}

Aytaç, Ö., Kurtdaş, M. Ç. (2015). Sağlık-Hastalığın Toplumsal Kökenleri ve Sağlık Sosyolojisi, Firat Üniversitesi Sosyal Bilimler Dergisi, (25), 231-250.

Breton, D. L. (2015). Acının Antropolojisi, İ. Yerguz (Trans.), İstanbul: Sel.

Breton, D. L. (2019). Bedene Veda, A. U. Kılıç (Trans.) İstanbul: Sel.

Dastur, F. (2019). Ölümle Yüzleşmek, S. Oruç (Trans.), İstanbul: Pinhan.

Ellul, J. (2012). Sözün Düşüşü, H. Arslan (Trans.), İstanbul: Paradigma.

Heidegger, M. (1998). Bilim Üzerine İki Ders, H. Hünler (Trans.), İstanbul: Paradigma.

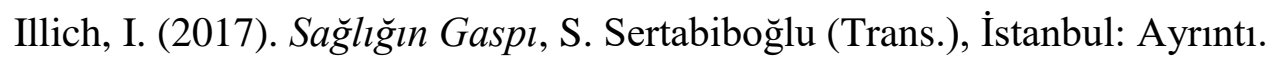

Sezgin, D. (2011). Tıbbileştirilen Yaşam Bireyselleştirilen Sağlık, İstanbul: Ayrıntı.

Zimmerman, M. E. (2011). Heidegger/Moderniteyle Hesaplaşma: Teknoloji, Politika, Sanat, H. Arslan (Trans.), İstanbul: Paradigma.

\footnotetext{
i “"Skin' Cioran says, 'is mortal to the extent of folly, to the extent of madness; it is not only the hotbed of diseases, it is the disease itself; it is the incurable nothingness, is a fabrication that has degenerated into a scourge." Breton, ibid., p.10.
}

ii One of the best examples of this understanding is undoubtedly the work called Machine-Man by the philosopher
and physician Julian Offray de La Mettrie (1709-1751), one of the important names of French materialism.

iii "Technologies are not content with enveloping daily life, they infiltrate into private life, enable people to get used to life and soothe him/her. The person finds the solution in technologies to feel what he needs to feel about the world around him. By programming himself pharmacologically, man extends his powers beyond his ordinary universe. Psychotropic substances present themselves as technical assistants of life, adjust the approach of the person to daily life, establish the fantasy of self-control in the face of the chaos of the world, lead to the cyborgization of the individual, the erasure of the boundaries between what is related to the self in a behavior and what is related to an external technique." Breton, ibid..,p.63.

iv The free will debate is not yet philosophically or theologically over. Both freedom as a value and the existence of free will are highly controversial.

${ }^{v}$ As it is known, pain also has social functions. For example, pain has an educational function. Pain also has a socially unifying dimension. Pain is about socialization, acceptance: initiation rituals are a prime example of this. Again, pain is not something that is often avoided in sports. "The athlete... thinks of pain as a raw material of the work he performs with his body... What is violence for society is pain for the boxer." Breton, David Le, Acının Antropolojisi, p.195, 196. On the social functions of pain, see, ibid., pp.163-207.

${ }^{\text {vi }}$ As culture has been medicalized, people have come to a point where they do not know what to do without experts. In fact, as in the Ruben example, the "losses" and "deficiencies" in people's bodies (ears, arms, legs, etc.) can be eliminated in some way or there can be a solution (hearing aids, prostheses). However, when there is no solution or a solution cannot be reached, medical culture says nothing about what people will do, how they will make sense of what they see as a loss or deficiency.

\footnotetext{
vii See about it, Ellul, Jacques, Sözün Düşüşü, trans. Hüsamettin Arslan, Paradigma Yayınları, İstanbul, 2012.

viii See also Heidegger's impressive account of this, Heidegger, Martin, Bilim Üzerine İki Ders, trans. Hakkı Hünler Paradigma Yayınları, İstanbul, 1998.
} 
Goodbye to the Body and The Sound of Silence in the Example of the Movie "Sound of Metal" 